\title{
THE ROLE OF PSYCHOLOGICAL CAPITAL IN MEDIATION OF THE EFFECT OF PROTEAN CAREER ORIENTATION ON PSYCHOLOGICAL WELL-BEING
}

\author{
Ni Made Mas Anindya Sthira Sista and I Gusti Ayu Manuati Dewi \\ Faculty of Economics and Business, Udayana University, Bali, Indonesia
}

http://doi.org/10.35409/IJBMER.2021.3278

\begin{abstract}
To improve the psychological well-being of employees, organizations must have more value offered to employees. One of the values that can be offered is a clear career orientation and psychological capital. When an employee's protean career is high, which is seen from the employee feeling responsible for success and failure in his career, always showing an optimistic attitude towards his career and having the freedom to determine his career, it will affect the psychological well-being of employees, because employees feel able to take advantage of opportunities and create opportunities. to develop themselves, which at the same time can increase the psychological capital of employees because automatically employees have hope for their careers. The sample used is a contract employee at the Department of Industry and Trade of the Province of Bali and Denpasar City, totaling 112 respondents with a sample collection technique using a saturated sample. This research uses PLS (Partial Least Square) analysis technique. The results of the study found that protean career orientation had a significant positive effect on psychological well-being. Protean career orientation has a significant positive effect on psychological capital. Psychological capital has a significant positive effect on psychological well-being. Psychological capital acts as a partial mediating variable on the effect of protean career orientation on psychological well-being.
\end{abstract}

Keyword: Psychological Well-being, Psychological Well-being, Psychological Capital.

\section{INTRODUCTION}

Organizations need to pay attention to the welfare, especially psychological well-being of contract employees. Employees with high levels of psychological well-being can develop a psychological state by showing positive attitude and behavior, such as higher productivity and performance (Kersemaekerset al., 2018). Individuals who have a high level of psychological well-being feel comfortable with themselves, trust relationships with others, and feel that they are on the right track in life (Park et al., 2017). The workplace situation plays a prominent role in influencing the psychological well-being of employees because a safe, comfortable and pleasant workplace causes employees to feel psychologically prosperous and tends to spend most of their time seeking fulfillment of their physiological and social needs (Hsu et al., 2019).

The problem of low psychological well-being arises because of the causes of several things such as career orientation (Prestiet al., 2018). Li (2018) argues that there is a positive relationship between protean career orientation and psychological well-being. Briscoe et al., (2012) in his 


\section{International Journal of Business Management and Economic Review}

Vol. 4, No. 04; 2021

ISSN: 2581-4664

research stated that the self-directed dimension of protean career orientation has a positive and significant relationship with psychological well-being. Rahim (2020) states that there is a positive and significant relationship between protean career orientation and psychological wellbeing because individuals with protean careers always show an optimistic attitude in managing assessments of situations and giving emotional responses and can directly improve psychological well-being.

Through career orientation, an individual can show behavior that reflects serious connotations of work, organization, and career (Sharjeel, et al., 2016). There are several types of career orientations that are most prominent, namely protean careers and boundaryless careers (Supeli and Creed, 2016). The protean career model emphasizes individual goals as a driver for career direction, while the boundaryless model seeks to explain how individuals manage career advancement in various organizational structures (Supeli and Creed, 2016). .

Protean career orientation is defined as an attitude to develop one's own definition of what constitutes a successful career, taking action to achieve these success criteria and motivation to adapt to a changing environment (Alonderiene and Simkeviciute, 2018). Individuals with protean careers tend to form beliefs about their careers, pursue personally desired career goals and behave in ways that are consistent with personal goals and values (Stauffer et al., 2018). Individuals who have a high protean career orientation are more value driven in the way they develop themselves and their careers (McGinley et al., 2020).

The effect of protean career orientation on psychological well-being is also influenced by psychological capital variables (Li, 2018). Mustafa et al., (2019) stated that protean career orientation has a positive and significant relationship with psychological capital because when someone has a protean career orientation (self-directed), the individual needs to have higher selfefficacy, hope, resilience, and optimism to achieve career success. Individuals with a protean career orientation have a good work-life balance and are positively related to psychological capital (Direnzo et. al 2015). Li (2018) which states that there is a positive and significant relationship between protean career orientation and psychological capital, because protean career orientation can facilitate psychological capital in order to motivate individuals to make career plans and explore career options.

Salles and d'Angelo (2020) define psychological capital as an individual who can make life more productive and valuable, and realize his potential. Employees with high psychological capital will tend to pursue goals more effectively, by getting the same benefits at work (Ramalu and Janadari, 2020). Psychological capital affects a person's career and personal achievement and affects people's behavior in many ways and places more emphasis on strength, success, happiness and can improve performance (Zhao et al., 2020).

Employees with a high level of psychological capital hold a positive assessment of the workplace based on events and circumstances, and employees tend to achieve personal growth and build positive relationships with others, therefore the level of psychological capital of employees in the organization plays a role in improving psychological well-being that can be achieved in everyday life (Bakker and Oerlemans, 2012). Garcia and Ayala's research (2017) states that psychological capital has a positive and significant influence on psychological well-being. Psychological capital is significantly related to psychological well-being, this shows that an increase in psychological capital also leads to an increase in psychological well-being (Xuet al., 2020).

From the description of some of the studies above, it can be seen that protean career orientation 


\section{International Journal of Business Management and Economic Review}

Vol. 4, No. 04; 2021

ISSN: 2581-4664

is able to affect psychological capital and psychological capital is also able to affect psychological well-being, on the other hand, protean career orientation is also able to affect psychological well-being. This shows that psychological capital is a variable mediating the relationship between the protean career orientation and psychological well-being variables. When an employee's protean career is high, which is seen from the employee feeling responsible for success and failure in his career, always showing an optimistic attitude towards his career and having the freedom to determine his career, it will affect the psychological well-being of employees, because employees feel able to take advantage of opportunities and create opportunities. to develop themselves, which at the same time can increase the psychological capital of employees because automatically employees have hope for their careers. This statement is also supported by research by Li (2018) which states that there is a relationship between protean career orientation and psychological well-being mediated by psychological capital.

\section{LITERATURE REVIEW AND HYPOTHESES DEVELOPMENT}

In $\mathrm{Li}(2018)$, it is stated that there is a positive relationship between protean career orientation and psychological well-being. Prestiet al., (2018) suggests that by managing one's own career development, various beneficial effects can be achieved, such as psychological well-being which is the most common career psychological outcome. Briscoe et al., (2012) in his research stated that the self-directed dimension of protean career orientation has a positive and significant relationship with psychological well-being. According to Rahim (2020) states that there is a positive and significant relationship between protean career orientation and psychological wellbeing because individuals with protean careers always show an optimistic attitude in managing assessments of situations and the resulting emotional responses and can directly improve psychological well-being. With the findings described previously, the researcher will re-examine the protean career orientation and psychological well-being by formulating the hypothesis, namely, the protean career orientation has a positive and significant effect on psychological wellbeing.

Research from Mustafa et al., (2019) stated that protean career orientation has a positive and significant relationship with psychological capital because when someone has a protean career orientation (self-directed), the individual needs to have higher self-efficacy, hope, resilience, and optimism to achieve career success. Sen and Hooja (2015) stated that protean career orientation and psychological capital have a positive influence on individuals, therefore from an organizational perspective, it is important to develop psychological capital and protean career orientation for employees, it will develop resources effectively and efficiently. efficient because individuals who have high psychological capital and are protean career oriented will need less direction and supervision by superiors.

Individuals with a protean career orientation have a good work-life balance and are positively related to psychological capital (Direnzo et. al 2015). Li(2018) supports the previous statement, which states that there is a positive and significant relationship between protean career orientation and psychological capital, because protean career orientation can facilitate psychological capital in order to motivate individuals to make career plans and explore career options, which in turn can encourage and enhance individual psychological resources. With the findings described previously, the researcher will re-examine the protean career orientation and 


\section{International Journal of Business Management and Economic Review}

Vol. 4, No. 04; 2021

ISSN: 2581-4664

psychological capital by formulating the hypothesis, namely, the protean career orientation has a positive and significant effect on psychological capital.

Research from Park et al., (2017), stated that psychological capital has a positive and significant relationship with psychological well-being. It is also supported by research by Youssef-Morgan and Luthans (2015), which states that there is a positive and significant relationship between psychological capital and psychological well-being, because psychological capital can affect psychological well-being when individuals are able to optimize the strength and capacity of their own resources. the individual himself. Malekitabaret al., (2017) stated that there is a significant relationship between psychological capital and psychological well-being. Psychological capital has a positive and significant relationship with individual well-being which is reflected in performance, because psychological capital is related to bringing improvement in individuals both personally and professionally (Tang, 2020). Psychological capital is significantly related to psychological well-being, this shows that an increase in psychological capital also leads to an increase in psychological well-being (Xuet al., 2020).

Employees with a high level of psychological capital hold a positive assessment of the workplace based on events and circumstances, and employees tend to achieve personal growth and build positive relationships with others, therefore the level of psychological capital of employees in the organization plays a role in improving psychological well-being that can be achieved in everyday life (Bakker and Oerlemans, 2012). According to Kim et al., (2018) stated that the psychological capital of employees will be positively related to psychological well-being. With the findings described previously, the researcher will re-examine psychological capital and psychological well-being by formulating a hypothesis, namely, psychological capital has a positive and significant effect on psychological well-being.

Previous research from Li (2018) stated that psychological capital mediates the effect of protean career orientation on psychological well-being. This psychological well-being variable or psychological well-being refers to an individual being able to assess himself and his ability to meet the basic needs in his life, where these basic needs such as self-acceptance, environmental mastery, autonomy, positive relationships, personal growth and life goals, which will affect with a clear career orientation for employees, because the protean career emphasizes individual goals as a driver for career direction and can directly cause employee psychological capital to be high, which is seen from employees being able to utilize their psychological strengths to achieve goals and encourage performance.

From the previous literature which states that protean career orientation is able to affect psychological capital and psychological capital is also able to affect psychological well-being. This shows that psychological capital is a variable mediating the influence between the protean career orientation and psychological well-being variables, due to the limitations of previous research related to the effect of protean career orientation on psychological well-being mediated by psychological capital, the researchers will examine the effect of protean career orientation on psychological well-being mediated by psychological capital by formulating a hypothesis, namely, the role of psychological capital in mediating the effect of protean career orientation on psychological well-being.

\section{METHODS}

This research uses a quantitative approach and is an associative research. This study was 


\section{International Journal of Business Management and Economic Review}

Vol. 4, No. 04; 2021

ISSN: 2581-4664

conducted to obtain empirical evidence and analyze the effect of protean career orientation on psychological well-being, the effect of protean career orientation on psychological capital, and the effect of psychological capital on psychological well-being. Also to further examine the role of protean career orientation on psychological well-being mediated by psychological capital. The scope of this research area is on contract employees of the Department of Industry and Trade of the Province of Bali and Denpasar City. The research was conducted at the Bali Provincial Office and Denpasar City because it is an agency that is the center of the economy and tourism in Bali, so the activities and workloads are automatically denser and the psychological well-being of employees should be considered. This location was chosen due to several problems related to psychological well-being of contract employees in the Department of Industry and Trade of the Province of Bali and Denpasar City. The data collection technique used is a questionnaire in the form of a statement given to the respondent to be filled in according to the actual situation.

Questionnaires distributed to respondents in the form of a list of online questions using Google Form. The population in this study were all contract employees at the Department of Industry and Trade of the Province of Bali and Denpasar City. The reason for using a population of contract employees is that the psychological well-being (psychological welfare) for contract employees has not been fulfilled, especially for the Department of Industry and Trade of the Province of Bali and Denpasar City, because some contract employees show a condition that only hangs out and cooperates in terms of work with colleagues who are considered close. ; and in terms of providing additional tasks, civil servants only entrust to contract employees who are considered and are used to doing this. This means that personal growth does not run well, because there is no system of learning, change and growth in it. The sampling technique in this study uses non-probability sampling with saturated sampling technique. The sample used in this study amounted to 112 people, with a sample of Bali Province contract employees totaling 38 people and Denpasar City contract employees totaling 74 people. Inferential analysis in this study uses PLS (Partial Least Square) with SmartPLS 3.0 program.

\section{RESULTS AND DISCUSSION}

Evaluation of goodness of fit from the outer model (Measurement model)

In evaluating the goodness of fit of the outer model (measurement model), three criteria are used, namely, convergent validity, discriminant validity and composite reliability. Evaluation of the measurement model based on the outer loading for reflective indicators with criteria, namely the reflective indicator is considered valid if it has a loading value above 0.50 and or a t-statistic value above 1.96 which means the model has convergent validity.

1) Convergent validity

The following are the results of the convergent validity test of the indicators of psychological well-being, protein career orientation and psychological capital variables, which are presented in Table 1.

The results of the analysis presented in Table 1. shows that the loading factor of all variable dimensions has a value above 0.5 . The results of the analysis show that all values of the loading factor dimensions of the psychological well-being variable have formed the psychological wellbeing variable, that positive relations is the most dominant dimension as a measure of the psychological well-being variable because it has the largest loading factor of 0.860 . The value of the loading factor dimension of the protean career orientation variable shows that both 


\section{International Journal of Business Management and Economic Review}

Vol. 4, No. 04; 2021

ISSN: 2581-4664

dimensions significantly form the protean career orientation variable, where values-driven is the most dominant dimension in forming the protean career orientation variable with a loading factor of 0.923 . The value of the loading factor dimension of the psychological capital variable shows that the dimensions significantly form the psychological capital variable, where hope is the most dominant dimension in forming the psychological capital variable with a loading factor of 0.864.Result of Convergent Validity can be seen at Table 1.

Table 1. Convergent validity test results

\begin{tabular}{|lll|}
\hline Variable & Indicators & $\begin{array}{l}\text { Outer } \\
\text { Loading }\end{array}$ \\
\hline \multirow{3}{*}{ Psychological well-being (Y) } & Self acceptance & 0,739 \\
& Positive relations & 0,860 \\
& Autonomy & 0,807 \\
& Environmental mastery & 0,791 \\
& Life purpose & 0,747 \\
& Personal growth & 0,568 \\
\hline Protean career orientation (X) & Self-directed & 0,909 \\
& Values-driven & 0,923 \\
\hline Psychological capital.(M) & Self-efficacy & 0,801 \\
& Hope & 0,864 \\
& Optimism & 0,863 \\
& Resilience & 0,831 \\
\hline
\end{tabular}

Primary data, 2021

2) Discriminant validity

Evaluation of the measurement model based on cross loading is used to assess whether the construct has good discriminant validity. Discriminant validity is considered valid if it has a cross loading of each indicator on the relevant variable having the largest value compared to the cross loading of other latent variables. The results of the cross loading of the three variables are presented at Table 2 .

Table 2. Discriminant validity test results

\begin{tabular}{|llcl|}
\hline & $\begin{array}{l}\text { Protean } \\
\text { Orientation }\end{array}$ & CareerPsychological Capital & Psychological Well-being \\
\hline $\mathrm{M}_{1}$ & 0.569 & $\mathbf{0 . 8 0 1}$ & \\
$\mathrm{M}_{2}$ & 0.670 & $\mathbf{0 . 8 6 4}$ & 0.411 \\
$\mathrm{M}_{3}$ & 0.661 & $\mathbf{0 . 8 6 3}$ & 0.476 \\
$\mathrm{M}_{4}$ & 0.566 & $\mathbf{0 . 8 3 1}$ & 0.588 \\
$\mathrm{X}_{1}$ & $\mathbf{0 . 9 0 9}$ & 0.692 & 0.622 \\
$\mathrm{X}_{2}$ & $\mathbf{0 . 9 2 3}$ & 0.657 & 0.493 \\
$\mathrm{Y}_{1}$ & 0.600 & 0.621 & 0.638 \\
$\mathrm{Y}_{2}$ & 0.564 & 0.611 & $\mathbf{0 . 7 3 9}$ \\
\hline
\end{tabular}




\section{International Journal of Business Management and Economic Review}

Vol. 4, No. 04; 2021

ISSN: $2581-4664$

\begin{tabular}{|llll|}
\hline \hline$Y_{3}$ & 0.447 & 0.395 & $\mathbf{0 . 8 0 7}$ \\
$Y_{4}$ & 0.469 & 0.437 & $\mathbf{0 . 7 9 1}$ \\
$Y_{5}$ & 0.340 & 0.405 & $\mathbf{0 . 7 4 7}$ \\
$Y_{6}$ & 0.207 & 0.160 & $\mathbf{0 . 5 6 8}$ \\
\hline
\end{tabular}

Primary data, 2021

Table 2 shows that the cross loading obtained by each latent variable is higher than the other latent variables so it can be said that the latent variable has met discriminant validity, it can be seen that the correlation of the psychological well-being construct $(\mathrm{Y})$ with its indicators is higher than the correlation with indicators of protean career orientation $(\mathrm{X})$ and psychological capital (M).

The correlation of the construct of protean career orientation (X) with its indicators is higher than the correlation with indicators of organizational commitment (Y) and psychological capital (M). The correlation of the psychological capital $(\mathrm{M})$ construct with its indicators is higher than the correlation with the protean career orientation $(\mathrm{X})$ and psychological well-being $(\mathrm{Y})$ indicators.

2) Composite reliability

Construct reliability of the measurement model with reflective indicators can be measured by looking at the composite reliability value and reinforced by Cronbach's Alpha value. The value of composite reliability and Cronbach's Alpha is good if it has a value higher than0.60. The following are the results of the instrument reliability research presented in Table 3.

Table 3. Composite reliability test results

\begin{tabular}{|lllll|}
\hline No. & Variable & $\begin{array}{l}\text { Cronbach's } \\
\text { Alpha }\end{array}$ & $\begin{array}{l}\text { Composite } \\
\text { Reliability }\end{array}$ & Information \\
\hline 1 & Psychological well-being (Y) & 0,856 & 0,888 & Reliable \\
2 & Protean career orientation (X) & 0,809 & 0,913 & Reliable \\
3 & Psychological capital.(M) & 0,861 & 0,905 & Reliable \\
\hline
\end{tabular}

Primary Data, 2021

Table 3 shows that the value of composite reliability and the value of Cronbach's Alpha for all constructs has a value of more than 0.60 . Thus, in the research model, each research construct has good reliability. 


\section{International Journal of Business Management and Economic Review}

Vol. 4, No. 04; 2021

ISSN: 2581-4664

Evaluation of structural model or inner model

Testing of the inner model or structural model is carried out to see the relationship between the construct, significance value and R-square of the research model. The coefficient of determination (R2) of each dependent variable is presented in Table 4 below:

Table 4. R-square

\begin{tabular}{|ll|}
\hline Construct & R-square \\
\hline Psychological well-being (Y) & 0,451 \\
Psychological capital (M) & 0,541 \\
\hline
\end{tabular}

Primary Data, 2021

Table 4 shows that the R-square value of the psychological well-being variable is 0.451 . It can be interpreted that $45.1 \%$ of the variability of the psychological well-being construct is explained by psychological capital and protean career orientation variables, while the remaining $54.9 \%$ of psychological well-being variables are explained by variables outside the model. Likewise, the psychological capital variable has an R-square value of 0.541 , meaning that $54.1 \%$ of the variability is explained by protean career orientation and psychological well-being, while the remaining $45.9 \%$ of psychological capital variables is explained by variables outside the model.

$\mathrm{R}$-square, goodness of fit model is also measured using the Q-square predicate relevance for structural models, measuring how well the observations made by the model and also the estimated parameters. The $\mathrm{Q}^{2}$ value $>0$ indicates the model has predicate relevance, on the other hand if the $\mathrm{Q}^{2}$ value 0 indicates the model has no predicate relevance. Table 4 can be calculated the value of predicate relevance $\left(\mathrm{Q}^{2}\right)$, namely:

$Q^{2}=1-\left(1-R 1^{2}\right)\left(1-R 2^{2}\right)$

$=1-(1-0,451)(1-0,541)$

$=1-(0,549)(0,459)$

$=1-0,251$

$=0,749$.

The results of this calculation indicate that the value of Q2 is greater than $0(=0.749)$, so it can be interpreted that the model is good because it has a relevant predictive value of $74 \%$. This shows that variations in psychological well-being variables can be explained by the variables used, namely psychological capital and protean career orientation variables, while $26 \%$ are explained by other variables outside this research model.

\section{Hypothesis test}

Hypothesis testing is done by t-test, which is sorting out direct and indirect effects testing or testing mediating variables. In the following section, the results of the direct influence test and the mediating variable test are described, respectively. 
International Journal of Business Management and Economic Review

Vol. 4, No. 04; 2021

ISSN: 2581-4664

Direct Effect Test

This study uses a Partial Least Square (PLS) analysis approach to test the research hypotheses that have been stated previously. The results of the analysis of the empirical model of the research conducted using Partial Least Square (PLS) analysis can be seen in Figure 1 below.

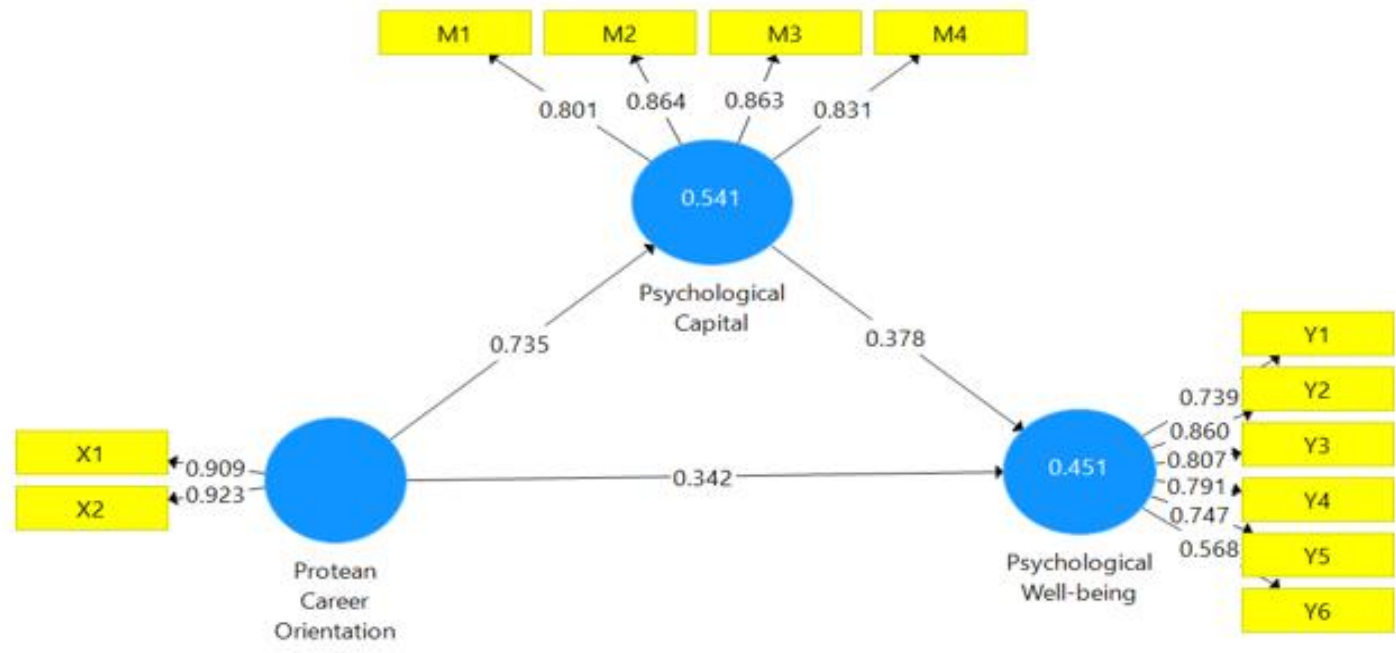

Figure 1. Empirical research model

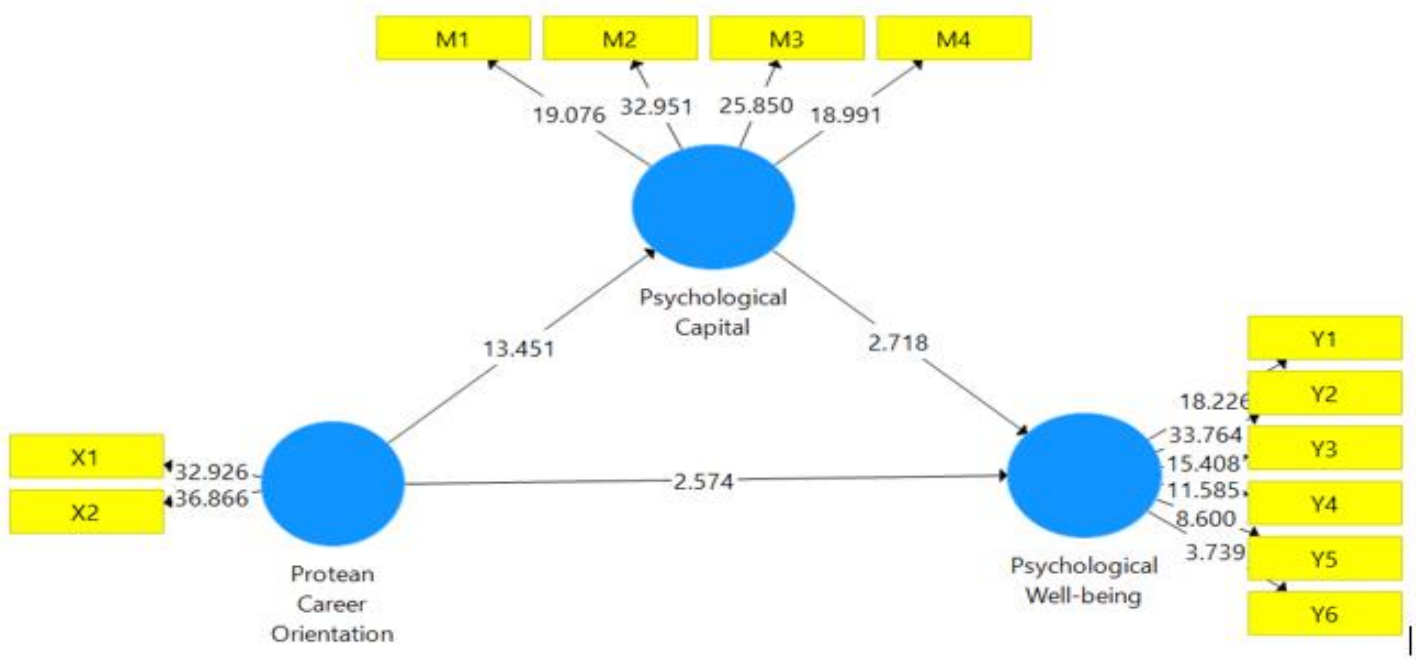

Figure 2. Bootstrapping

Figure 2 describes the results of bootstrapping in this study and is explained further in the following table 5 . 
International Journal of Business Management and Economic Review

Vol. 4, No. 04; 2021

ISSN: 2581-4664

Table 5. The results of direct effect test

\begin{tabular}{|lllll|}
\hline Construct & $\begin{array}{l}\text { Path } \\
\text { Coefficient }\end{array}$ & t-statistics & P values & Information \\
\hline $\begin{array}{l}\text { Protean career orientation } \\
\text { >psychological well-being } \\
\text { Protean career orientation }\end{array}$ & $-0,342$ & 2,574 & 0,005 & Accepted \\
$\begin{array}{l}\text { psychological capital } \\
\text { Psychological capital } \\
\text { >psychological well-being }\end{array}$ & $-0,3735$ & 13,451 & 0,000 & Accepted \\
\hline
\end{tabular}

Primary Data, 2021

Hypothesis testing is done by using t-statistics and looking at the p-value. The value of $t$ statistics value of t-table (1.96) or p-value $<0.05$, then $\mathrm{H} 0$ is rejected and the research hypothesis is accepted. Table 5.10 shows that the protean career orientation variable has a correlation coefficient value of 0.342 and a t statistic value of 2.574 , so H1 is accepted. This shows that there is a positive influence between protean career orientation on psychological well-being. The higher the protean career orientation of the contract employee, the higher the psychological wellbeing he has in him.

The protean career orientation variable has a correlation coefficient value of 0.735 and at statistic value of 13.451 , so $\mathrm{H} 2$ is accepted. This shows that there is a positive influence of protean career orientation on psychological capital. The higher the protean career orientation of contract employees, the higher the psychological capital they have. Furthermore, the psychological capital variable has a correlation coefficient value of 0.378 and a t statistic value of 2.718 , so H3 is accepted. This shows that there is a positive influence between psychological capital on psychological well-being. The higher the psychological capital in contract employees, the higher the psychological well-being they have.

Testing the mediating role of psychological capital on the protean variable orientation to psychological well-being

The results of testing the direct effect of employee protean career orientation on psychological well-being have a p-value of 0.005; where this value is smaller than the Alpha used, which is $5 \%$ (0.05). This shows that there is a significant positive effect between employee protean career orientation on psychological well-being, with a coefficient value of 0.342 . The addition of psychological capital as a mediator has a different effect on the direct relationship of protean career orientation to psychological well-being. The psychological capital mediating test for employees is done by calculating the Variance Accounted For (VAF) value. The following is the calculation of the Variance Accounted For (VAF) value: 


\section{International Journal of Business Management and Economic Review}

Vol. 4, No. 04; 2021

ISSN: 2581-4664

$$
\begin{array}{rr}
V A F=\quad \frac{\text { Indirect Effect }}{\text { Total Effect }} \\
0,278 \quad 0,620=0,448
\end{array}
$$

From the results of previous calculations, it can be seen that the role of psychological capital as a mediator has a VAF value of $0.448(44.8 \%)$. These results indicate that employee psychological capital has a mediating role between employee protean career orientation and psychological well-being. This shows that if the higher the protean career orientation possessed by contract employees, the higher the psychological capital of contract employees at work and will be able to improve the psychological well-being of employees, so the hypothesis which states that psychological capital acts as a mediator of the relationship between protean career orientation and psychological well-being is proven.

\section{The effect of protean career orientation on psychological well-being}

The data presented in Table 5 shows that employee protein career orientation has a significant positive effect on psychological well-being. The protean career indicators are able to improve the psychological well-being of contract employees of the Department of Industry and Trade of the Province of Bali and Denpasar City. The results of this study explain that the higher the protean career orientation of contract employees towards their careers, the higher the psychological wellbeing felt by employees in themselves.

Employees' high protein career orientation is seen from employees who feel responsible for success or failure in their careers, employees feel that the most important thing in their careers is freedom in determining their careers, and they don't care what other people think about their career decisions. With a high protean career, there is a link to high psychological well-being. This is indicated by the high level of psychological well-being of employees, employees feel able to establish close relationships with others, take advantage of opportunities and create opportunities to develop themselves, have clear life goals, individual abilities to continue to develop their potential and are able to determine their own destiny.

The results in this study are in line with the results of research conducted by Prestiet al., (2018), Rahim (2020), Li (2018), and Briscoe et al., (2012). This finding implies that contract employees with a high protean career always show an optimistic attitude in managing the assessment of the situation and the emotional response of their work, which can directly improve psychological well being in employees. When contract employees have a high protean career orientation, it can be seen from employees being given the opportunity to operationalize their personal values at work, helping employees to have a feeling of success and satisfaction with their careers, will directly be able to improve the psychological well-being of employees, because employees feel 


\section{International Journal of Business Management and Economic Review}

Vol. 4, No. 04; 2021

ISSN: 2581-4664

relevant to the organization.

\section{The effect of protean career orientation on psychological capital}

The data presented in Table 5 shows that employee protein career orientation has a significant positive effect on psychological capital. Protean career indicators are able to increase the psychological capital of contract employees of the Department of Industry and Trade of the Province of Bali and Denpasar City. The results of this study explain that the higher the protean career orientation that contract employees have towards their careers, the higher the psychological capital in employees will be.

Employees' high protein career orientation is seen from employees who feel responsible for success or failure in their careers, employees feel that the most important thing in their careers is freedom in determining their careers, and they don't care what other people think about their career decisions. With a high protean career, there is a link to high psychological capital. This is indicated by the high level of psychological capital of employees, seen from employees being able to mobilize motivation, employees believe in setting achievable goals, determining paths to achieve goals and developing special plans to achieve goals, feelings of success in achieving goals to achieve targets, and able to overcome conflicts, difficulties, failures or even challenges

The results in this study are in line with the results of research conducted by Mustafa et al., (2019), Li, Y. (2018), Direnzo, et al., (2015), and Sen and Hooja (2015). This finding implies that when contract employees have a protean career orientation (self-directed) in themselves, these employees need to have higher self-efficacy, hope, resilience, and optimism to achieve career success. Protean career orientation can facilitate psychological capital to be able to motivate employees to make career plans and explore career options, which in turn can encourage and increase employees' psychological resources.

\section{The effect of psychological capital on psychological well-being}

The data presented in Table 5 shows that the psychological capital of employees has a significant positive effect on psychological well-being. Psychological capital indicators are able to improve the psychological well-being of contract employees of the Department of Industry and Trade of the Province of Bali and Denpasar City.The results of this study explain that the higher the psychological capital possessed by contract employees, the higher the psychological well-being of employees.

Psychological capital refers to personality characteristics that affect the efficiency of contract employees' work to achieve goals and encourage performance. When employees have the opportunity to develop and grow within the organization, they will be able to improve their psychological well-being, because employees feel they have opportunities and create opportunities to develop themselves.

The results in this study are in line with the results of research conducted by Youssef-Morgan and Luthans (2015), Park et al., (2017), Malekitabaret al., (2017), Tang (2020), Bakker and 


\section{International Journal of Business Management and Economic Review}

Vol. 4, No. 04; 2021

ISSN: 2581-4664

Oerlemans (2012), Kim et al., (2018), and Xuet al., (2020). This finding implies that when contract employees have high psychological capital, these employees can hold a positive assessment of the workplace based on events, circumstances and employees tend to be able to achieve personal growth and build positive relationships with others, therefore the level of psychological capital of employees in in the organization plays a role in improving psychological well-being that can be achieved in everyday life.

The role of psychological capital mediates the effect of protean career orientation on psychological well-being

The results of the analysis show that psychological capital is able to positively mediate the indirect effect of protean career orientation on psychological well-being. These results can be interpreted that the higher the level of protean career orientation, it can increase psychological capital, so that in the end psychological well-being will increase. The results in this study indicate that $\mathrm{H} 4$ is accepted.

Psychological capital can partially mediate the relationship between protean career orientation and psychological well-being for contract employees of the Industry and Trade Office of Bali Province and Denpasar City. The higher the psychological capital of contract employees, the higher the influence of protean career orientation on psychological well-being.

\section{CONCLUSION}

Protean career orientation has a positive and significant influence on psychological well-being. Employees who have a high protean career will be responsible for their career and career success and manage careers based on personal assessment, of course, it will affect the psychological well-being of employees because employees feel personal growth in themselves, have good environmental control and have a purpose in life. clear.

Both protean career orientations have a positive and significant influence on psychological capital. Employees who have a high protein career will be responsible for their careers and career success and manage their careers based on personal assessment, of course, this will affect the increase in psychological capital because employees always see the good side of their work and are optimistic about future work.

The three psychological capitals have a positive and significant influence on psychological wellbeing. Employees who have high psychological capital will see the good side of their work and are optimistic about future work, of course, it will affect their psychological well-being because they feel personal growth in themselves, have good environmental control and clear life goals.

Psychological capital partially mediates the effect of protean career orientation on psychological well-being, because when the employee's protean career is high, seen from the employee's perspective, they feel responsible for success and failure in their career; always shows an optimistic attitude towards his career and has the freedom to determine his career, will affect the psychological well-being of employees, because employees feel able to take advantage of 


\section{International Journal of Business Management and Economic Review}

Vol. 4, No. 04; 2021

ISSN: 2581-4664

opportunities and create opportunities to develop themselves, which will also increase employee psychological capital, because employees feel they already have hope for their careers.

\section{REFERENCES}

Alonderiene, R., and Simkeviciute, I. 2018. Linking protean and boundaryless career with organizational commitment. Baltic Journal of Management, 13(4), 471-487.

Al-Zyoud, M.F., and Mert, I.S. 2019. Does employees psychological capital buffer the negative effects of incivility?. EuroMed Journal of Business, 14(3), 239-250.

Armaou, M., Konstantinidis, S., and Blake, H. 2019. The effectiveness of digital interventions for psychological well-being in the workplace: a systematic review protocol. International Journal of Environmental Research and Public Health, 17(1), 255.

Bakker, A. B., and Oerlemans, W. G. M. 2012. Subjective well-being in organizations. The Oxford handbook of positive organizational scholarship, 1(1), 178-189.

Baruch, Y., Wordsworth, R., Mills, C., and Wright, S. 2015. Career and work attitudes of bluecollar workers, and the impact of a natural disaster chance event on the relationships between intention to quit and actual quit behaviour. European Journal of Work and Organizational Psychology, 25(3), 459-473.

Briscoe, J.P., Henagan, S.C., Burton, J.P., and Murphy, W.M. 2012. Coping with an insecure employment environment: The differing roles of protean and boundaryless career orientations. Journal of Vocational Behavior, 80(1), 308-316.

Direnzo, M.S., Greenhaus, J.H., and Weer, C.H. 2015. Relationship between protean career orientation and work life balance: A resource perspective. Journal of Organizational Behavior, 36(4), $538-560$.

Enwereuzor, I. K., Ugwu, L. E. and Nnadozie, E. E. 2020. Dynamics of person-supervisor fit in relationship quality and well-being of university academicians. Personnel Review, Vol. ahead-ofprint No. ahead-of-print.

García, G. M., and Ayala, J. C. 2017. Relationship between psychological capital and psychological well-being of direct support staff of specialist autism services: The mediator role of burnout. Frontiers in Psychology, 8(2277), 1-12.

Gao, Q., Wu, C., Wang, L., and Zhao, X. 2020. The entrepreneur's psychological capital, creative innovation behavior, and enterprise performance. Frontiers in Psychology, 11(1651), 112.

Gubler, M., Arnold, J., and Coombs, C. 2014. Reassessing the protean career concept: Empirical findings, conceptual components, and measurement. Journal of Organizational Behavior, 35(1), $23-40$. 


\section{International Journal of Business Management and Economic Review}

Vol. 4, No. 04; 2021

ISSN: 2581-4664

Guo, L. X., Liu, C. F., and Yain, Y.S. 2020. Social entrepreneur's psychological capital, political skills, social networks and new venture performance. Frontiers in Psychology, 11(925), 1-10.

Hair, J.E., Hult, G.T.M., Ringle, C.M., and Sarstedt, M. 2014. A Primer on Partial Least Squares Structural Equation Modeeling (PLS-SEM). SAGE Publications,Inc.: California. USA.

Halbesleben, J. R. B., Neveu, J., Paustian-Underdahl, S. C., and Westman, M. 2014. Getting to the "COR": Understanding the role of resources in conservation of resources theory. Journal of Management, 20(10), 1-31.

Hobfoll, S. E., Halbesleben, J., Neveu, J. P., and Westman, M. 2018. Conservation of resources in the organizational context: The reality of resources and their consequences. Annual Review of Organizational Psychology and Organizational Behavior, 5(1), 103-128.

Holtmaat, K., van der Spek, N., Lissenberg-Witte, B. I., Cuijpers, P., and Verdonck-de Leeuw, I. M. 2018. Positive mental health among cancer survivors: overlap in psychological well-being, personal meaning, and post traumatic growth. Supportive Care in Cancer, 27(2), 443-450.

Hsu, F. S., Liu, Y. A., and Tsaur, S. H. 2019. The impact of workplace bullying on hotel employees' well-being: Do organizational justice and friendship matter. International Journal of Contemporary Hospitality Management, 31(4), 1702-1719.

Joo, B.K., and Lee, I. 2017. Workplace happiness: work engagement, career satisfaction, and subjective well-being. Evidence-Based HRM: a Global Forum for Empirical Scholarship, 5(2), 206-221.

Kersemaekers, W., Rupprecht, S., Wittmann, M., Tamdjidi, C., Falke, P., Donders, R., Speckens, A. and Kohls, N. 2018. A workplace mindfulness intervention may be associated with improvedpsychological well-being and productivity. A preliminaryfield study in a company setting. Frontiers in Psychology, 9(195), 1-11.

Khan, M. L., Salleh, R., and Hemdi, M.A.B. 2016. Effect of protean career attitudes on organizational commitment of employees with moderating role of organizational career management. International Review of Management and Marketing, 6(4), 155-160.

Kim, M., Kim, A. C. H., Newman, J. I., Ferris, G. R. and Perrewe, P. L. 2018. The antecedents and consequences of positive organizational behavior: The role of psychological capital for promoting employee well-being in sport organizations. Sport Management Review, Elsevier, 22(1), 108-125.

Kim, S., and Kweon, Y. 2020. Psychological capital mediates the association between job stress and burnout of among Korean psychiatric nurses. Healthcare, 8(3), 199.

Kong, F., Tsai, C.H., Tsai, F.S., Huang, W. and Cruz, S.M. 2018. Psychological capital research: a meta-analysis and implications for management sustainability. Sustainability, 10(3457), 1-9. 


\section{International Journal of Business Management and Economic Review}

Vol. 4, No. 04; 2021

ISSN: 2581-4664

Kostal, J.W., and Wiernik, B.M. 2017. A meta-analytic investigation of demographic differences in protean, boundaryless, and proactive career orientations. Career Development International, 22(5), 520-545.

Li, Y. 2018. Linking protean career orientation to well-being: the role of psychological capital. Career Development International, 23(2), 178-196.

Lopez, J., Rojo, G. P., Noriega, C., Carretero, I., Velasco, C., Martines, H.J.A., Frutos, P. L., and Galarraga, L. 2020. Psychological well-being among older adults during the COVID-19 outbreak: a comparative study of the young-old and the old-old adults. International Journal of Psychogeriatrics, 32(11), 1365-1370.

Luthans, F., Avey, J.B., Avolio, B.J. and Peterson, S. 2010. The development and resulting performance impact of positive psychological capital. Human Resource Development Quarterly, 21(1), 41-67.

Kemenpan RB, 2018. Kementerian Pendayagunaan Aparatur Negara dan Reformasi Birokrasi. [Online] Available at: https://www.menpan.go.id/site/berita-terkini/berita-daerah/jumlah-umkmdi-kota-denpasar-alami-peningkatan-lima-tahun-terakhir [Accessed 2712 2020].

Malekitabar, M., Riahi, M., and Reza Malekitabar, A. 2017. The Role of psychological capital in psychological well-being and job burnout of high schools principals in Saveh, Iran. Iranian Journal of Psychiatry and Behavioral Sciences, 11(1), 1-8.

McGinley, S., Line, N.D., Wei, W., and Peyton, T. 2020. Studying the effects of future-oriented factors and turnover when threatened. International Journal of Contemporary Hospitality Management, 32(8), 2737-2755.

Mustafa, M., Nor M.N.M., and Omar, S. 2019. Impact of protean career orientation on academic's career success: The mediating role of psychological capital. Journal of Technology Management and Business, 6(2), 60-74.

Okurame, D.E., and Fabunmi, R. 2014. Protean and boundaryless careers: Exploring the role of mentoring and gender in the context of a major African country. Career Development International, 19(1), 73-100.

Paramita A.R., M. Rahardjo, dan S. Sofian. 2007. Analisis faktor-faktor yang mempengaruhi OCB pegawai kontrak (studi pada pegawai kontrak di lingkungan universitas diponogoro semarang). Jurnal Studi Manajemen Organisasi, 4(2), 61-69.

Park, J. G., Kim, J. S., Yoon, S.W. and Joo, B.K. 2017. The effects of empowering leadership on psychological well-being and job engagement: The mediating role of psychological capital. Leadership dan Organization Development Journal, 38(3), 350-367.

Pang, H. 2018. Understanding the effects of WeChat on perceived social capital and psychological well-being among Chinese international college students in Germany. Aslib 


\section{International Journal of Business Management and Economic Review}

Vol. 4, No. 04; 2021

ISSN: 2581-4664

Journal of Information Management, 70(3), 288-304.

Presti, A. L., Pluviano, S., and Briscoe, J. P. 2018. Are freelancers a breed apart? The role of protean and boundaryless career attitudes in employability and career success. Human Resource Management Journal, 28(3), 427-442.

Rahim, N. B. 2020. The interaction between protean career orientation, career goal development and well-being outcomes: Evidence from Professional Engineers, Gadjah Mada International Journal of Business, 22(1), 24-48.

Ramalu, S. S., and Janadari, N. 2020. Authentic leadership and organizational citizenship behaviour: the role of psychological capital. International Journal of Productivity and Performance Management, 50(3), 371-384.

Ryff, C. D., and Singer, B. H. 2008. Know thyself and become what you are : A eudaemonic approach to psychological well-Being. Journal of HappinessStudies, 9(1), 13-39.

Salles, F. L. P., and d'Angelo, M. J. 2020. Assessment of psychological capital at work by physiotherapists. Physiotherapy Research International. 25(3), 1-6.

Sen C., and Hooja H. R. 2015. Developing Indian human resource: Role of psychological capital and protean career orientation. Indian Journal of Positive Psychology, 6(3), 311-314.

Sharjeel, M. Y., Siddiqui, H. and Khawaja, G. 2016. Work-family conflict and career orientation amongst employed women in banks and hospitals. Pakistan Business Review, 17(4), 950-964.

Sorensen, S., Steindl, S. R., Dingle, G. A., and Garcia, A. 2018. Comparing the effects of lovingkindness meditation (LKM), music and LKM plus music on psychological well-being. The Journal of Psychology, 153(3), 267-287.

Stauffer, S. D., Abessolo, M., Zecca, G., and Rossier, J. 2018. French-language translation and validation of the protean and boundaryless career attitudes scales: Relationships to proactive personality, career adaptability, and career satisfaction. Journal of Career Assessment, 27(2), 337-357.

Sugiyono. 2019. Metode Penelitian Kuantitatif Kualitatif dan R\&D. Edisi ke 2, Cetakan 1. Bandung: CV. Alphabeta.

Sugiyono. 2019. Statistika Untuk Penelitian. Edisi ke 30. Bandung: CV. Alfabeta

Supeli, A. and Creed, P. A., 2016. The longitudinal relationship between protean career orientation and job satisfaction, organizational commitment, and intention-to-quit. Journal of Career Development , 43(1), 66-80.

Tang, J. J. 2020. Psychological capital and entrepreneurship sustainability. Frontiers in Psychology, 11(1), 866-878. 
International Journal of Business Management and Economic Review

Vol. 4, No. 04; 2021

ISSN: 2581-4664

Umar, Husein. 2011. Metode Penelitian untuk Skripsi dan Tesis Bisnis, Edisi Kedua. Jakarta :PT. Raja Grafindo Persada.

Wang, X., Guchait, P., and Pasamehmetoglu, A. 2020. Why should errors be tolerated? Perceived organizational support, organization based self-esteem and psychological well-being. International Journal of Contemporary Hospitality Management, 32(5), 1987-2006.

Wong, S. C., Rasdi, R.M., Samah, B.A., and Wahat, N.W.A. 2017. Promoting protean career through employability culture and mentoring: career strategies as moderator. European Journal of Training and Development, 41(3), 277-302. 